medRxiv preprint doi: https://doi.org/10.1101/2020.12.28.20248962; this version posted January 4, 2021. The copyright holder for this preprint

(which was not certified by peer review) is the author/funder, who has granted medRxiv a license to display the preprint in perpetuity.

It is made available under a CC-BY-NC-ND 4.0 International license.

Tissue-specific differential gene expression in AMD

\title{
The ocular tissue-specificity of differentially expressed age-related macular degeneration
}

\section{associated genes}

Dylan Duchen ${ }^{a *}$ and Terri Beaty ${ }^{\mathrm{a}}$

${ }^{a}$ Department of Epidemiology, Johns Hopkins Bloomberg School of Public Health, Baltimore, MD 21205

* Corresponding author: Dylan Duchen, E-mail: dduchen3@jhu.edu

\section{Financial support}

This work was supported by the National Eye Institute's Predoctoral Eye \& Vision Genomics Training Grant, T32-EY022303.

\section{Conflicts of interest}

None of the authors have any proprietary interests or conflicts of interest related to this submission. 
medRxiv preprint doi: https://doi.org/10.1101/2020.12.28.20248962; this version posted January 4, 2021. The copyright holder for this preprint (which was not certified by peer review) is the author/funder, who has granted medRxiv a license to display the preprint in perpetuity.

It is made available under a CC-BY-NC-ND 4.0 International license .

Tissue-specific differential gene expression in AMD

The ocular tissue-specificity of differentially expressed age-related macular degeneration associated genes

Purpose: Age-related macular degeneration (AMD) is a leading cause of blindness in the developed world. One of the most genetically well-characterized degenerative diseases, genome-wide association studies (GWAS) have identified 52 independent common or rare AMD risk associated variants. While transcriptome-wide association analyses (TWAS) and expression quantitative trait loci (eQTL) efforts have characterized the effects of these AMD-associated genes on mRNA expression in retinal tissue, we aimed to characterize the AMD-associated transcriptional profiles of functionally distinct ocular tissues including the macular and extramacular regions of the retina and the retinal-pigment epithelium (RPE)/choroid.

Methods: Using publicly available microarray data (NCBI GEO accession: GSE29801) comprised of retinal and RPE/choroidal tissue samples from 142 AMD patients and 151 healthy individuals (118 retina and 175 RPE/Choroid samples), tissue-specific differential gene expression analyses were conducted. Transcriptome analyses were focused on 878 genes surrounding known AMD-associated loci.

$\underline{\text { Results: }}$ Many genes which contain clinically significant or causal variants identified via GWAS or TWAS/eQTL studies were significantly differentially expressed and display transcriptional heterogeneity across different subtypes of ocular tissue and retinal geography in AMD-associated tissues.

Conclusion: These findings demonstrate the importance of spatial heterogeneity and tissue specificity in the mRNA expression of known AMD-associated genes. Genes known to harbor rare or causal AMDassociated variants are differentially expressed in functionally distinct ocular tissues of AMD patients, suggesting they might contribute to disease regardless of mutation status.

Keywords: Age-related macular degeneration, AMD, Transcriptome, Differential Gene Expression 
medRxiv preprint doi: https://doi.org/10.1101/2020.12.28.20248962; this version posted January 4, 2021. The copyright holder for this preprint (which was not certified by peer review) is the author/funder, who has granted medRxiv a license to display the preprint in perpetuity.

It is made available under a CC-BY-NC-ND 4.0 International license .

Tissue-specific differential gene expression in AMD

1

2

3

4

5

6

7

8

\section{Introduction}

Age-related macular degeneration (AMD) is one of leading causes of blindness in the developed world and is a growing problem in developing countries where average life expectancies are increasing. ${ }^{1}$ Based on several population-based cohorts, the estimated prevalence of AMD is $0.2 \%$ in people aged 55-64 years and rises to $13 \%$ in people older than $85 .^{2}$ While a range of conditions may result in macular degeneration, AMD reflects the progressive accumulation of drusen, deposits of proteins, lipids, and trace elements, which aggregate within and beneath the retina and the retinal pigment epithelium (RPE). AMD presents in three distinctive categories depending on the severity of vision loss; early AMD, intermediate AMD, and advanced AMD. Advanced AMD results from regions of geographic atrophy, the loss of focal areas of the RPE and its supporting blood vessels, or neovascularization. Neovascular AMD has an acute onset and can lead to detachment of RPE tissue or the retina, resulting in severe central vision loss. ${ }^{3}$ Additional classifications exist, including 'wet' (choroidal neovascularization with angiogenesis) and the more common ‘dry’ AMD (geographic atrophy without angiogenesis).

European-ancestry, in addition to age and tobacco use, ${ }^{2,3}$ is a major risk factor for developing AMD.

These ancestry-related differences persist despite those of European-ancestry having the same prevalence of drusen deposits as other ethnicities. ${ }^{4-7}$ A role for genetics in AMD development was initially supported by familial aggregation studies, ${ }^{8}$ with the complement factor $H(C F H)$ gene being identified as AMDassociated in one of the earliest genome-wide association studies (GWAS). ${ }^{9}$ Subsequent GWAS have resulted in AMD being one of the most genetically well-characterized degenerative retinal diseases. ${ }^{10-16}$ The most recent GWAS involved a cohort of 16,144 AMD cases and 17,832 controls, testing over 12 million variants for association with various AMD subtypes. ${ }^{17}$ Bringing the total number of independent variants associated with risk of AMD to 52 (involving 34 different genetic regions), this GWAS identified three genes $(C F H, C F I$, and $T I M P 3)$ as harboring rare $(\mathrm{MAF}<0.1 \%)$ causal variants and a fourth gene (SLC16A8) harboring a potentially causal splice variant and estimated the additive genetic effects of these 
medRxiv preprint doi: https://doi.org/10.1101/2020.12.28.20248962; this version posted January 4, 2021. The copyright holder for this preprint (which was not certified by peer review) is the author/funder, who has granted medRxiv a license to display the preprint in perpetuity.

It is made available under a CC-BY-NC-ND 4.0 International license .

Tissue-specific differential gene expression in AMD

markers combined accounts for $46.7 \%$ of the variability in risk of AMD among those of European ancestry. ${ }^{17}$

While rare causal variants can hint at underlying biological mechanisms of AMD and may completely explain the etiology of AMD for a few individuals, the extent to which rare causal mutation-associated genes affect AMD risk among individuals without these mutations remain unclear. Determining whether these genes are also differentially expressed in AMD compared to normal eye tissue could suggest additional mechanisms by which these genetic factors contribute to the pathogenesis of AMD. While Fritsche, et al. surveyed the mRNA expression for the 368 genes closest to the recognized 34 regions of interest in healthy retinal or choroidal tissues via RNAseq ${ }^{17}$ AMD-derived tissues have been shown to have significantly different transcriptome profiles compared to normal ocular tissue. ${ }^{18-23}$ Recently, a transcriptome-wide association analysis (TWAS) and expression quantitative trait loci (eQTL) study comparing diseased to healthy retinal tissues identified additional causal variants across these 34 GWASidentified risk loci and characterized the effects of AMD-associated variants on gene expression within the retina. ${ }^{24}$

As gene expression is spatially heterogenous and differs across functionally distinct tissues and regions within the eye, these findings may ignore tissue-specific expression differences relevant to AMD pathogenesis. For example, neither the combined GWAS study of Fritsche et al. or Ratnapriya et al.'s TWAS/eQTL study included RPE/choroidal-specific AMD tissues or attempted to distinguish between macular and extramacular regions of the retina (Figure 1). ${ }^{25}$ Thus, it remains unclear whether the genes identified by these large genomic studies are differentially expressed in AMD patients within distinct geographical regions or certain tissue subtypes. Leveraging publicly available data, ${ }^{23}$ we aimed to determine whether these GWAS-associated genes are aberrantly expressed in AMD compared to healthy tissues within retinal and RPE/choroidal tissues. Identifying the distinct tissues and regions in which AMD-associated genetic factors are aberrantly expressed will improve our understanding of AMD 
medRxiv preprint doi: https://doi.org/10.1101/2020.12.28.20248962; this version posted January 4, 2021. The copyright holder for this preprint (which was not certified by peer review) is the author/funder, who has granted medRxiv a license to display the preprint in perpetuity.

It is made available under a CC-BY-NC-ND 4.0 International license .

Tissue-specific differential gene expression in AMD

pathogenesis and potentially aid drug development efforts by revealing novel mechanisms by which genetic factors contribute to disease.

\section{$51 \quad$ Materials and methods}

52 Publicly available transcriptome data was obtained through NCBI's Gene Expression Omnibus (GEO),

53 accession GSE29801, using the GEOquery (v2.48.0) package in R. Tissue acquisition, RNA purification,

54 and microarray hybridization methods have been described previously. ${ }^{23,26}$ The two channel Agilent

55 Whole Genome 4x44 K in situ oligonucleotide array platform (G4112F, Agilent Technologies, Inc., Santa

56 Clara, CA, USA) was used to assess global transcriptome mRNA expression utilizing a pooled reference

57 panel consisting of equal parts RPE-choroid and retinal RNA. A dye-swap design was implemented

58 where samples from the pooled reference and tissues of interest were labeled with alternating dye-labels

59 to minimize the chance of systemic dye effects. During the preprocessing stage, experimental and pooled

60 reference samples were assigned to the appropriate channels as if no dye-swap were conducted, benefiting

61 from the dye-swap design without requiring any downstream dye-related normalization steps. Samples

62 were background corrected by subtracting the background intensities from the foreground intensities, as

63 previously described. ${ }^{23}$ Within-array normalization was conducted via loess normalization followed by

64 quantile normalization across arrays, according to the limma (v3.36.3) differential gene expression-

65 focused software package. ${ }^{27}$

66 Negative and positive control probes as well as the lowest expression probes were filtered out by

67 computing the $95^{\text {th }}$ percentile of the negative control probes for each array, and then retaining probes

68 which were at least $10 \%$ brighter than these values in at least four arrays. Duplicate probes $(\mathrm{N}=253)$

69 within each array were collapsed by their mean, resulting in a total of 33,237 unique probes. Probe-to-

70 gene annotation was accomplished using the Agilent "Human Genome, Whole" annotation package

71 hgug4112a.db (v3.2.3) accessed via the Bioconductor suite of R packages. ${ }^{28}$ As our intended level of

72 inference is the gene level, the probe with the highest inter-quartile range across all samples was selected

73 to represent genes containing multiple mapped probes, resulting in 16,716 unique genes available for 
medRxiv preprint doi: https://doi.org/10.1101/2020.12.28.20248962; this version posted January 4, 2021. The copyright holder for this preprint (which was not certified by peer review) is the author/funder, who has granted medRxiv a license to display the preprint in perpetuity.

It is made available under a CC-BY-NC-ND 4.0 International license .

Tissue-specific differential gene expression in AMD

74 analysis. Differential gene expression analysis was conducted by first stratifying by tissue-source

75 (macular region, extramacular region, retina, RPE/choroid, macular retina, macular RPE/choroid,

76 extramacular retina, and extramacular RPE/choroid) and then fitting linear models for the mRNA

77 expression of each gene with the empirical Bayes method according to the limma differential gene

78 expression guidelines..$^{27,29}$

79 Written consent was obtained from all participants or their surviving relatives under protocols which

80 adhered to the guidelines described by the Declaration of Helsinki, as previously described. ${ }^{23}$ This

81 previous study was approved by the St. Louis University, the University of Iowa, the University of Utah,

82 and the University of California, Santa Barbara institutional review boards. ${ }^{23}$

\section{Results}

84 The large GWAS conducted by Fritsche et al. identified 34 loci achieving genome-wide significance,

85 corresponding to regions containing 878 different genes, defined by linkage-disequilibrium (LD) ( $\mathrm{r}^{2} \geq 0.5$,

$86 \pm 500 \mathrm{~kb}) \cdot{ }^{17}$ Of these 878 genes, 650 were annotated and expressed $(74 \%)$ in our analysis of RNA

87 expression. Using a narrower LD defined region surrounding the 52 most significantly associated markers

$88\left(\mathrm{r}^{2} \geq 0.5, \pm 100 \mathrm{~kb}\right), 368$ unique genes were located within these regions and used by Fritsche et al., for

89 subsequent analyses. Of these 368 genes, 274 (74.5\%) were annotated and found to be expressed in our

90 analysis of RNA expression in 8 different retinal tissues.

91 After stratifying by both tissue origin and region, 289 genes were differentially expressed (FDR $<20 \%$ )

92 within the macula of the retina, while in RPE/choroid tissues more genes in the extramacular region were

93 differentially expressed (a total of 889 genes) compared to the macula (only 86 genes). Combining

94 macular and extramacular retinal samples, differential gene expression analyses identified 2,491

95 differentially expressed genes $(p<0.05)$ in retinal tissues $(\mathrm{N}=118), 590$ with $\mathrm{FDR}<10 \%$. Of these genes,

96123 were also identified in the large GWAS study, 58 of these genes located within the narrow windows

97 of LD surrounding 34 recognized risk loci. Twenty-nine of the GWAS-identified genes included within 
medRxiv preprint doi: https://doi.org/10.1101/2020.12.28.20248962; this version posted January 4, 2021. The copyright holder for this preprint (which was not certified by peer review) is the author/funder, who has granted medRxiv a license to display the preprint in perpetuity.

It is made available under a CC-BY-NC-ND 4.0 International license .

Tissue-specific differential gene expression in AMD

the wider LD cutoffs were significantly differentially expressed between AMD and healthy tissues at a FDR $<10 \%$, of which the following 17 genes fell within the narrowly LD-defined subset of 368 different genes: $C 4 B, C F B, H L A-B, H L A-D Q A 2, T M E M 116, H L A-C, A P O E, C 3, H L A-D R A, H T R A 1, C L I C 1$, MMP19, ABCA1, PLTP, TRPM3, TNXB, and HSPH1 (Table 1). The three genes (HLA-DQB2, CYP21A2, and GALR3) were determined to not be expressed in healthy retinal tissue according to the RNAseq analysis conducted by Fritsche et al. yet were significantly differentially expressed in AMD vs. healthy retina tissue in this analysis. ${ }^{17} \mathrm{CFI}$ and $T I M P 3$, two of the three genes identified as potentially harboring causal rare variants (i.e. those with $\mathrm{MAF}<0.1 \%$ ), were also differentially expressed in AMD-diagnosed retinal tissue (i.e. showing higher expression in AMD compared to healthy retina with FDRs of $12.7 \%$ and $17.5 \%$ respectively).

In RPE/choroid tissue $(\mathrm{N}=175)$, a total of 2,452 genes were differentially expressed (at $p<0.05)$, and 443 yielded a FDR $<10 \%$. Among these genes, 104 had been previously identified within the wider LD regions surrounding the 34 most significant genes by Fritsche et al. while 52 were within the narrow LD regions. Ten of these genes were significantly differentially expressed between AMD and healthy tissues (defined as FDR<10\%): SLC25A10, COL8A1, HCP5, SRPK2, MRPL12, HLA-DRB1, APOC1, GDF11, PILRB, and VEGFA (Table 1). Comparing mRNA expression results generated here to the RNAseq results from healthy RPE/choroid tissues conducted by Fritsche et. al., seven genes (UGT3A2, TNXB, BTNL2, HLA-DQA2, HLA-DOB, CKM, TIMP3) were discordant in that they showed differential expression in AMD vs. healthy RPE/choroid $(p<0.05)$ while they were not expressed in the RNAseq analysis of healthy retina/choroid tissues. As noted above, TIMP3 $(p=0.039, \mathrm{FDR}=31.2 \%)$ had been previously identified as potentially containing rare causal variants $(\mathrm{MAF}<0.1 \%)$.

Genes included within the narrow-LD regions surrounding the recognized GWAS risk loci identified as significantly differentially expressed (at FDR $<10 \%)$ in extramacular RPE/choroid tissue $(\mathrm{N}=84)$ included: DDAH2, BLOC1S1, PILRB, COL8A1, ARHGAP21, HCP5, and APOM, all of which were reported to be expressed by Fritsche et al.'s RNAseq analysis. Additional findings for macular-specific 
medRxiv preprint doi: https://doi.org/10.1101/2020.12.28.20248962; this version posted January 4, 2021. The copyright holder for this preprint (which was not certified by peer review) is the author/funder, who has granted medRxiv a license to display the preprint in perpetuity.

It is made available under a CC-BY-NC-ND 4.0 International license .

Tissue-specific differential gene expression in AMD

123

124

125

126

127

128

129

130

131

132

133

134

135

136

137

138

139

140

141

142

143

144

145

146

retina, macular-specific RPE/choroid, extramacular-retina, macular retina and RPE/choroid combined, and extramacular retina and RPE/choroid combined are shown in Table 1. Using a relatively loose FDR threshold of $20 \%$, the narrow-LD region defined genes COL8A1, HCP5, APOM, HSPA1A, HLA-DQA2, VEGFA, and HERPUD1 showed differential expression in both retina and RPE/choroid tissue.

Attempts at characterizing mRNA expression of AMD-associated genes is not a novel concept. ${ }^{25}$ Comparing our results to a recently conducted TWAS and expression quantitative trait loci (eQTL) analysis in bulk retina tissue, ${ }^{24} 10$ significantly differentially expressed genes (FDR $<20 \%$ ), including PLTP, HLA-DQB1, CFI, TMEM199, HERPUD1, NIT2, PILRB, PLA2G12A, BLOC1S1, and TOMM40 were previously identified as either a target gene of causal variants or was found to contain TWAS/eQTLassociated variants. Genes identified in Ratnapriya et al.'s eQTL/TWAS analysis which were differentially expressed (FDR $<20 \%$ ) solely within the retina include CFB, APOE, PLTP, HLA-DQB1, TMEM199, CFI, C2, and CD63. Differentially expressed eQTL/TWAS-identified genes specific to RPE/choroid include BLOC1S1, SRPK2, PLA2G12A, SLC16A8, TOMM40, and potentially PILRB (all of these genes were differentially expressed within RPE/choroid tissues, extramacular RPE/choroid tissues, as well as extramacular tissues of retina and RPE/choroid combined). Genes differentially expressed across both retina and RPE/choroid were emphasized in the eQTL/TWAS analysis and included COL8A1, HERPUD1, and NIT2. B3GLCT, one of two genes strongly suggested as being causal for AMD pathogenesis in the TWAS/eQTL study, was not included in these results because $B 3 G L C T$-specific probes were not included in the Agilent annotation package. Individual probe-level analysis of probes mapping to $B 3 G L C T$ showed a marginal difference in expression in retinal AMD tissues $(p=0.03, \mathrm{FDR}=$ 27.5\%). However, the gene immediately upstream of B3GLCT, HSPH1, was included within the narrowLD regions surrounding the top GWAS loci and was significantly differentially expressed in AMDassociated retina tissue $(\mathrm{FDR}<10 \%)$.

\section{Discussion}


medRxiv preprint doi: https://doi.org/10.1101/2020.12.28.20248962; this version posted January 4, 2021. The copyright holder for this preprint (which was not certified by peer review) is the author/funder, who has granted medRxiv a license to display the preprint in perpetuity.

It is made available under a CC-BY-NC-ND 4.0 International license .

Tissue-specific differential gene expression in AMD

147 The retina includes 10 distinct layers serving varying biological functions and is composed of specialized

148 cells and substructures for photoreception and transmitting signals through the optic nerve. The RPE, a

149 single layer of epithelial cells supporting the neural retina with nutrients, is the basal layer of the retina

150 and is most distal from the vitreous filled interior of the eye. In addition to these layers being comprised

151 of multiple, disparate cell types, the distribution of certain cells is heterogenous across the retina. For

152 example, rod and cone cells, photoreceptors responsible for scotopic (low light, low acuity, and non-color

153 vision) and photopic (bright light, high acuity, and color vision) respectively, vary in density depending

154 on their proximity to the center of the macula. When the composition and the function of a tissue varies

155 spatially, so too does RNA transcription, transcriptional regulation, and the translation of genetic material.

156 The two main tissue types, the retina and RPE/choroid, as well as their respective regions (the macular

157 and extramacular regions) are important for development and progression of AMD. Determining whether

158 the contribution of recognized genes associated with risk to AMD is spatially or retinal tissue-type

159 specific should improve our understanding of the biological mechanisms underlying AMD development.

160 Genes differentially expressed between retina and RPE/choroid tissues, (e.g., HERPUD1, COL8A1,

$161 H C P 5, A P O M, H S P A 1 A, H L A-D Q A 2$, and $V E G F A$ ) may contribute to AMD pathogenesis by uniformly

162 affecting several tissue subtypes. However, when gene expression spatially differs between retinal and

$163 \mathrm{RPE} /$ choroid tissues (as it does for many genes associated with AMD) a potential interaction between

164 geographic region and tissue layer may exist. Because the macular region of the retina and extramacular

165 region of the choroid contain the most differentially expressed genes (in their respective tissue types), it

166 suggests a region/tissue specificity of the genetic architecture and pathogenesis of AMD.

167 These tissue and region-specific findings allow discrimination between retina or RPE/choroid-specific

168 signals, potentially providing evidence supporting the hypothesis that these signals may be more relevant

169 in the macular or extramacular regions. BLOC1S1, for example, was a TWAS-associated variant

170 containing gene and the gene targeted by the lead causal variant located within the $R D H 5 / C D 63$ region.

171 In this analysis, BLOC1S1 was differentially expressed only within the extramacular RPE/choroid (Figure 
medRxiv preprint doi: https://doi.org/10.1101/2020.12.28.20248962; this version posted January 4, 2021. The copyright holder for this preprint (which was not certified by peer review) is the author/funder, who has granted medRxiv a license to display the preprint in perpetuity.

It is made available under a CC-BY-NC-ND 4.0 International license .

Tissue-specific differential gene expression in AMD

172

173

174

175

176

177

178

179

180

181

182

183

184

185

186

187

188

189

190

191

192

193

194

195

196

2). Encoding a component of the BLOC1 protein complex required for the biogenesis and function of the endosomal-lysosomal system, BLOC1S1 was previously hypothesized to play a role in synaptic function. ${ }^{24}$ BLOC1S1's putative function as a transporter between endosomes and lysosomes, and the observation that a deficiency in certain subunits of the BLOC1-protein complex can result in accumulation of surface proteins could suggest a role in protein accumulation beneath the extramacular RPE/choroid. ${ }^{30,31}$ Indeed, extramacular drusen are associated with AMD development. ${ }^{32}$ The effect of overexpression of BLOC1S1 on BLOC1 activity, as well as this putative functional relationship warrant further study. PILRB, a gene identified in both the GWAS and TWAS/eQTL studies represents another gene differentially expressed within the RPE/choroid but not the retina, potentially indicating some tissuespecific role for the PILRB gene in AMD pathogenesis. We also observed two GWAS identified risk genes for AMD harboring rare non-synonymous variants, TIMP3 and CFI, as differentially expressed in retinal tissues critical to AMD. TIMP3 was marginally significantly differentially expressed in retina $(\mathrm{FDR}=17.5 \%)$ and extramacular choroid $(\mathrm{FDR}=15.6 \%)$ tissues, while $C F I$ was significantly differentially expressed in retina $(\mathrm{FDR}=12.7 \%)$. The characterization of genes containing rare variants (like TIMP3 and CFI) as significantly differentially expressed suggests some expanded functional role for these genes in development and pathogenesis of AMD independent of their mutation status. $\mathrm{CFH}$, the third rare-variant containing gene highlighted by Fritsche et al., was not differentially expressed in AMD compared to healthy tissue in either retina or the RPE/choroid, potentially indicating whatever its biological mechanism, $\mathrm{CFH}$-associated pathogenicity may not be mediated through altered RNA expression.

Information related to genetic ancestry of the donors was unavailable, potentially biasing the results and the generalizability of our findings as transcriptional regulation and mRNA expression can differ significantly depending on ancestry. ${ }^{34,35}$ While we can conclude these donor samples were not included in Fritsche et al.'s GWAS cohort, we cannot guarantee that our donor population is genetically similar to the source populations included in either Fritsche et al.'s GWAS or Ratnapriya et al.'s TWAS. Despite this 
medRxiv preprint doi: https://doi.org/10.1101/2020.12.28.20248962; this version posted January 4, 2021. The copyright holder for this preprint (which was not certified by peer review) is the author/funder, who has granted medRxiv a license to display the preprint in perpetuity.

It is made available under a CC-BY-NC-ND 4.0 International license .

Tissue-specific differential gene expression in AMD

197 limitation, the significant amount of overlap between results of this analysis and Fritsche et al. and

198 Ratnapriya et al.'s findings (see Results) suggests the donor samples utilized within this analysis were not

199 genetically distinct from those included in these previous GWAS or TWAS studies, a possibility as a

200 subset of donor samples from Fritsche et al. were also sourced from the University of Iowa and Oregon

201 Lions. $^{10,17,23,36}$

202 This research focuses on genes previously found to be associated with AMD in large GWAS and

203 TWAS/eQTL studies. These previous studies do not provide the geographic resolution to establish

204 whether differential expression of these genes is specific to unique regions in the eye or distinct tissue

205 layers. These findings highlight both the spatial and tissue-specific contribution of known risk genes for

206 AMD, adding depth to our understanding of the biological importance of these genetic risk factors for

207 AMD. Additional functional analyses are still needed to determine whether these identified regions and/or

208 tissue-specific expression of these genes are truly biologically meaningful or directly pathogenic.

209 Furthermore, while the prevalence of AMD and subsequently the genetic risk for AMD may be highest in

210 populations of European descent, AMD is certainly not exclusive to this population. ${ }^{33}$ While the effects of

211 genetic variation on RNA expression may be ancestry specific and suffer from the same generalizability

212 issues seen with GWAS studies. ${ }^{34,35}$ Large GWAS and tissue layer-specific eQTL-focused TWAS studies

213 with diverse cohorts are still needed to confirm whether these results hold for individuals of non-

214 European ancestry.

215 Acknowledgements

216 This work was supported by the National Eye Institute's Predoctoral Eye \& Vision Genomics Training

217 Grant, T32-EY022303. The authors would like to thank the volunteers and patients who participated in

218 the multiple studies from which publicly available microarray and any clinically associated metadata was

219 derived.

\section{Disclosure of interests}


medRxiv preprint doi: https://doi.org/10.1101/2020.12.28.20248962; this version posted January 4, 2021. The copyright holder for this preprint (which was not certified by peer review) is the author/funder, who has granted medRxiv a license to display the preprint in perpetuity.

It is made available under a CC-BY-NC-ND 4.0 International license .

Tissue-specific differential gene expression in AMD

221 The authors declare no conflict of interest.

222 Data availability

223 All data used to support the findings of this study are publicly available in NCBI's Gene Expression

224 Omnibus (GEO), accession GSE29801, at

225 https://www.ncbi.nlm.nih.gov/geo/query/acc.cgi?acc=GSE29801.

226 Supplemental data

227 Tissue-Specific Differential Gene Expression $(p<0.05)$ Results

228 References

229 1. Chakravarthy U, Evans J, Rosenfeld PJ. Age related macular degeneration. BMJ. 2010;340(feb26

230 1):c981-c981. doi:10.1136/bmj.c981

231

2. Smith W, Assink J, Klein R, et al. Risk factors for age-related macular degeneration: Pooled findings from three continents. Ophthalmology. 2001;108(4):697-704. doi:10.1001/archopht.119.10.1455

3. Coleman HR, Chan C-C, Ferris FL, Chew EY. Age-related macular degeneration. Lancet. 2008;372(9652):1835-1845. doi:10.1016/S0140-6736(08)61759-6 degeneration in a black population. The Barbados Eye Study Group. Arch Ophthalmol (Chicago, Ill 1960). 1995;113(6):728-735. http://www.ncbi.nlm.nih.gov/pubmed/7786213

5. Friedman DS, Katz J, Bressler NM, Rahmani B, Tielsch JM. Racial differences in the prevalence of age-related macular degeneration: the Baltimore Eye Survey. Ophthalmology. 1999;106(6):1049-1055. doi:10.1016/S0161-6420(99)90267-1

242 6. Age-Related Eye Disease Study Research Group. Risk factors associated with age-related macular degeneration. A case-control study in the age-related eye disease study: Age-Related Eye Disease 
medRxiv preprint doi: https://doi.org/10.1101/2020.12.28.20248962; this version posted January 4, 2021. The copyright holder for this preprint (which was not certified by peer review) is the author/funder, who has granted medRxiv a license to display the preprint in perpetuity.

It is made available under a CC-BY-NC-ND 4.0 International license .

Tissue-specific differential gene expression in AMD

Study Report Number 3. Ophthalmology. 2000;107(12):2224-2232. http://www.aaojournal.org/cgi/content/full/107/12/2224\%5Cnhttp://www.aaojournal.org/cgi/conte nt/abstract/107/12/2224\%5Cnhttp://www.ncbi.nlm.nih.gov/entrez/query.fcgi?cmd=Retrieve \&db= PubMed\&dopt $=$ Citation\&list_uids $=11097601$

7. Klein R, Klein BEK, Jensen SC, Mares-Perlman JA, Cruickshanks KJ, Palta M. Age-related maculopathy in a multiracial United States population: the National Health and Nutrition Examination Survey III. Ophthalmology. 1999;106(6):1056-1065. doi:10.1016/S01616420(99)90255-5

8. Heiba IM, Elston RC, Klein BE, Klein R. Sibling correlations and segregation analysis of agerelated maculopathy: the Beaver Dam Eye Study. Genet Epidemiol. 1994;11(1):51-67. doi:10.1002/gepi.1370110106

9. Klein RJ, Zeiss C, Chew EY, et al. Complement factor H polymorphism in age-related macular degeneration. Science. 2005;308(5720):385-389. doi:10.1126/science.1109557

10. Fritsche LG, Chen W, Schu M, et al. Seven new loci associated with age-related macular degeneration. Nat Genet. Published online 2013. doi:10.1038/ng.2578

11. Raychaudhuri $\mathrm{S}$, Iartchouk $\mathrm{O}$, Chin $\mathrm{K}$, et al. A rare penetrant mutation in $\mathrm{CFH}$ confers high risk of age-related macular degeneration. Nat Genet. Published online 2011. doi:10.1038/ng.976

12. Helgason $\mathrm{H}$, Sulem P, Duvvari MR, et al. A rare nonsynonymous sequence variant in $\mathrm{C} 3$ is associated with high risk of age-related macular degeneration. Nat Genet. Published online 2013. doi:10.1038/ng. 2740

13. Seddon JM, Yu Y, Miller EC, et al. Rare variants in CFI, C3 and C9 are associated with high risk of advanced age-related macular degeneration. Nat Genet. Published online 2013. doi:10.1038/ng.2741 
medRxiv preprint doi: https://doi.org/10.1101/2020.12.28.20248962; this version posted January 4, 2021. The copyright holder for this preprint (which was not certified by peer review) is the author/funder, who has granted medRxiv a license to display the preprint in perpetuity.

It is made available under a CC-BY-NC-ND 4.0 International license .

Tissue-specific differential gene expression in AMD

267

268

269

270

271

272

273

274

275

276

277

278

279

280

281

14. Zhan $\mathrm{X}$, Larson $\mathrm{DE}$, Wang $\mathrm{C}$, et al. Identification of a rare coding variant in complement 3 associated with age-related macular degeneration. Nat Genet. Published online 2013. doi:10.1038/ng.2758

15. Van De Ven JPH, Nilsson SC, Tan PL, et al. A functional variant in the CFI gene confers a high risk of age-related macular degeneration. Nat Genet. Published online 2013. doi:10.1038/ng.2640

16. Arakawa S, Takahashi A, Ashikawa K, et al. Genome-wide association study identifies two susceptibility loci for exudative age-related macular degeneration in the Japanese population. Nat Genet. Published online 2011. doi:10.1038/ng.938

17. Fritsche LG, Igl W, Bailey JNC, et al. A large genome-wide association study of age-related macular degeneration highlights contributions of rare and common variants. Nat Genet. 2016;48(2):134-143. doi:10.1038/ng.3448

18. Chowers I, Wong R, Dentchev T, et al. The iron carrier transferrin is upregulated in retinas from patients with age-related macular degeneration. Invest Ophthalmol Vis Sci. 2006;47(5):2135-2140. doi:10.1167/iovs.05-1135

19. Radeke MJ, Peterson KE, Johnson L V., Anderson DH. Disease susceptibility of the human macula: Differential gene transcription in the retinal pigmented epithelium/choroid. Exp Eye Res. Published online 2007. doi:10.1016/j.exer.2007.05.006

20. Anderson DH, Radeke MJ, Gallo NB, et al. The pivotal role of the complement system in aging and age-related macular degeneration: Hypothesis re-visited. Prog Retin Eye Res. Published online 2010. doi:10.1016/j.preteyeres.2009.11.003

21. Silveira AC, Morrison MA, Ji F, et al. Convergence of linkage, gene expression and association data demonstrates the influence of the RAR-related orphan receptor alpha (RORA) gene on neovascular AMD: A systems biology based approach. Vision Res. Published online 2010. 
medRxiv preprint doi: https://doi.org/10.1101/2020.12.28.20248962; this version posted January 4, 2021. The copyright holder for this preprint (which was not certified by peer review) is the author/funder, who has granted medRxiv a license to display the preprint in perpetuity.

It is made available under a CC-BY-NC-ND 4.0 International license .

Tissue-specific differential gene expression in AMD

doi:10.1016/j.visres.2009.09.016

291 22. Hunter A, Spechler PA, Cwanger A, et al. DNA methylation is associated with altered gene expression in AMD. Invest Ophthalmol Vis Sci. Published online 2012. doi:10.1167/iovs.11-8449

23. Newman AM, Gallo NB, Hancox LS, et al. Systems-level analysis of age-related macular degeneration reveals global biomarkers and phenotype-specific functional networks. Genome Med. 2012;4(2):16. doi:10.1186/gm315

24. Ratnapriya R, Sosina OA, Starostik MR, et al. Retinal transcriptome and eQTL analyses identify genes associated with age-related macular degeneration. Nat Genet. 2019;51(4):606-610. doi:10.1038/s41588-019-0351-9

25. Morgan DJ, DeAngelis MM. Differential gene expression in age-related macular degeneration. Cold Spring Harb Perspect Med. 2015;5(8):1-11. doi:10.1101/cshperspect.a017210

26. Radeke MJ, Peterson KE, Johnson L V., Anderson DH. Disease susceptibility of the human macula: Differential gene transcription in the retinal pigmented epithelium/choroid. Exp Eye Res. 2007;85(3):366-380. doi:10.1016/j.exer.2007.05.006

27. Ritchie ME, Phipson B, Wu D, et al. limma powers differential expression analyses for RNAsequencing and microarray studies. Nucleic Acids Res. 2015;43(7):e47-e47.

28. Carlson M. hgug4112a.db: Agilent "Human Genome, Whole" annotation data (chip hgug4112a). Published online 2016.

29. Smyth GK. Linear Models and Empirical Bayes Methods for Assessing Differential Expression in Microarray Experiments. Stat Appl Genet Mol Biol. Published online 2004. doi:10.2202/15446115.1027

312 30. Yang Q, He X, Yang L, et al. The BLOS1-Interacting Protein KXD1 is Involved in the Biogenesis 
medRxiv preprint doi: https://doi.org/10.1101/2020.12.28.20248962; this version posted January 4, 2021. The copyright holder for this preprint (which was not certified by peer review) is the author/funder, who has granted medRxiv a license to display the preprint in perpetuity.

It is made available under a CC-BY-NC-ND 4.0 International license .

Tissue-specific differential gene expression in AMD

of Lysosome-Related Organelles. Traffic. Published online 2012. doi:10.1111/j.1600-

0854.2012.01375.x

315 31. Setty SRG, Tenza D, Truschel ST, et al. BLOC-1 Is Required for Cargo-specific Sorting from Vacuolar Early Endosomes toward Lysosome-related Organelles. Mol Biol Cell. Published online

32. Ersoy L, Schick T, De Graft D, et al. Extramacular drusen are highly associated with age-related macular degeneration, but not with CFH and ARMS2 genotypes. Br J Ophthalmol. Published online 2016. doi:10.1136/bjophthalmol-2015-306806

33. Wong WL, Su X, Li X, et al. Global prevalence of age-related macular degeneration and disease burden projection for 2020 and 2040: a systematic review and meta-analysis. Lancet Glob Heal. 2014;2(2):e106-e116. doi:10.1016/S2214-109X(13)70145-1

324 34. Keys K, Mak ACY, White MJ, et al. On the cross-population portability of gene expression prediction models. bioRxiv. Published online 2019. doi:https://doi.org/10.1101/552042

35. Mogil LS, Andaleon A, Badalamenti A, et al. Genetic architecture of gene expression traits across diverse populations. Epstein MP, ed. PLOS Genet. 2018;14(8):e1007586.

36. Hageman GS, Anderson DH, Johnson L V., et al. A common haplotype in the complement regulatory gene factor $\mathrm{H}(\mathrm{HF} 1 / \mathrm{CFH})$ predisposes individuals to age-related macular degeneration. 


\begin{tabular}{|c|c|c|c|c|c|c|c|c|c|}
\hline & & Differ & $\begin{array}{c}\text { ntially Express } \\
0.05)\end{array}$ & d Genes $(p<$ & & ferentially Ex & ressed Genes & $F D R<10 \%)$ & \\
\hline Tissue & $\begin{array}{c}\text { Sample } \\
\text { s (N) }\end{array}$ & $\begin{array}{l}\text { Genes } \\
(\mathrm{N})\end{array}$ & $\begin{array}{c}\text { Overlapping } \\
\text { GWAS- } \\
\text { Identified } \\
\text { Genes (Wide } \\
\text { Margin, } \\
\text { N=878) }\end{array}$ & $\begin{array}{c}\text { Overlappin } \\
\text { g GWAS- } \\
\text { Identified } \\
\text { Genes } \\
\text { (Narrow } \\
\text { Margin } \\
\text { N=368) }\end{array}$ & $\begin{array}{l}\text { Genes } \\
(\mathrm{N})\end{array}$ & $\begin{array}{c}\text { Overlappin } \\
\text { g GWAS- } \\
\text { Identified } \\
\text { Genes } \\
\text { (Wide, } \\
\text { N=878) }\end{array}$ & $\begin{array}{c}\text { Overlappin } \\
\text { g GWAS- } \\
\text { Identified } \\
\text { Genes } \\
\text { (Narrow, } \\
\text { N=368) }\end{array}$ & $\begin{array}{c}\text { Overlapping } \\
\text { GWAS- } \\
\text { Identified } \\
\text { Genes (DE with } \\
\text { FDR < 10\%) }\end{array}$ & $\begin{array}{c}\text { Overlapping } \\
\text { TWAS- } \\
\text { Identified } \\
\text { Genes (DE } \\
\text { with FDR } \\
<\mathbf{2 0 \%} \text { ) }\end{array}$ \\
\hline Retina & 118 & 2491 & 123 & 58 & 590 & 29 & 17 & $\begin{array}{c}C 4 B, C F B, \\
H L A-B, H L A- \\
D Q A 2, \\
T M E M 116, \\
H L A-C, A P O E, \\
C 3, H L A-D R A, \\
H T R A 1, C L I C 1, \\
M M P 19, \\
A B C A 1, P L T P, \\
T R P M 3, T N X B, \\
H S P H 1\end{array}$ & $\begin{array}{c}\text { CFB, APOE, } \\
P L T P, H L A- \\
D Q B 1, C 2, \\
\text { CFI, } \\
\text { COL8A1, } \\
T M E M 199, \\
\text { CD63, } \\
\text { HERPUD1, } \\
\text { NIT2 }\end{array}$ \\
\hline RPE/Choroid & 175 & 2452 & 104 & 52 & 443 & 20 & 10 & $\begin{array}{c}\text { SLC25A10, } \\
\text { COL8A1, } \\
\text { HCP5, SRPK2, } \\
\text { MRPL12, HLA- } \\
\text { DRB1, APOC1, } \\
\text { GDF11, PILRB, } \\
\text { VEGFA }\end{array}$ & $\begin{array}{c}\text { COL8A1, } \\
\text { SRPK2, } \\
\text { PILRB, } \\
\text { HERPUD1, } \\
\text { PLA2G12A, } \\
\text { SLC16A8 }\end{array}$ \\
\hline Macular Retina & 60 & 1766 & 70 & 36 & 70 & 4 & 2 & $C 4 B, C 3$ & APOE, PLTP \\
\hline $\begin{array}{c}\text { Macular } \\
\text { RPE/Choroid }\end{array}$ & 91 & 1786 & 75 & 35 & 11 & 4 & 1 & $P B X 2$ & \\
\hline $\begin{array}{l}\text { Extramacular } \\
\text { RPE/Choroid }\end{array}$ & 84 & 2349 & 108 & 48 & 302 & 14 & 7 & $\begin{array}{c}\text { DDAH2, } \\
\text { BLOC1S1, } \\
\text { PILRB, } \\
\text { COL } 8 A 1, \\
\text { ARHGAP21, } \\
\text { HCP5. APOM }\end{array}$ & $\begin{array}{l}\text { BLOC1S1, } \\
\text { PILRB, } \\
\text { COL8A1, } \\
\text { TOMM40, } \\
\text { NIT2 }\end{array}$ \\
\hline
\end{tabular}


Tissue-specific differential gene expression in AMD

\begin{tabular}{|c|c|c|c|c|c|c|c|c|}
\hline $\begin{array}{c}\text { Extramacular } \\
\text { Retina }\end{array}$ & 58 & 1398 & 70 & 36 & 0 & 0 & 0 & 0 \\
\hline $\begin{array}{c}\text { Macula (retina } \\
+ \\
\text { RPE/Choroid) }\end{array}$ & 151 & 1367 & 58 & 25 & 5 & 0 & 0 & PILRB \\
\hline $\begin{array}{c}\text { Extramacular } \\
\text { (retina }+ \\
\text { RPE/Choroid) }\end{array}$ & 142 & 1212 & 63 & 31 & 2 & 0 & 0 \\
\hline
\end{tabular}

Table 1: Differentially Expressed Genes Stratified by Tissue and Geographic Region. Shaded rows indicate retina-specific tissue findings. 
medRxiv preprint doi: https://doi.org/10.1101/2020.12.28.20248962; this version posted January 4, 2021. The copyright holder for this preprint (which was not certified by peer review) is the author/funder, who has granted medRxiv a license to display the preprint in perpetuity. It is made available under a CC-BY-NC-ND 4.0 International license .

Tissue-specific differential gene expression in AMD

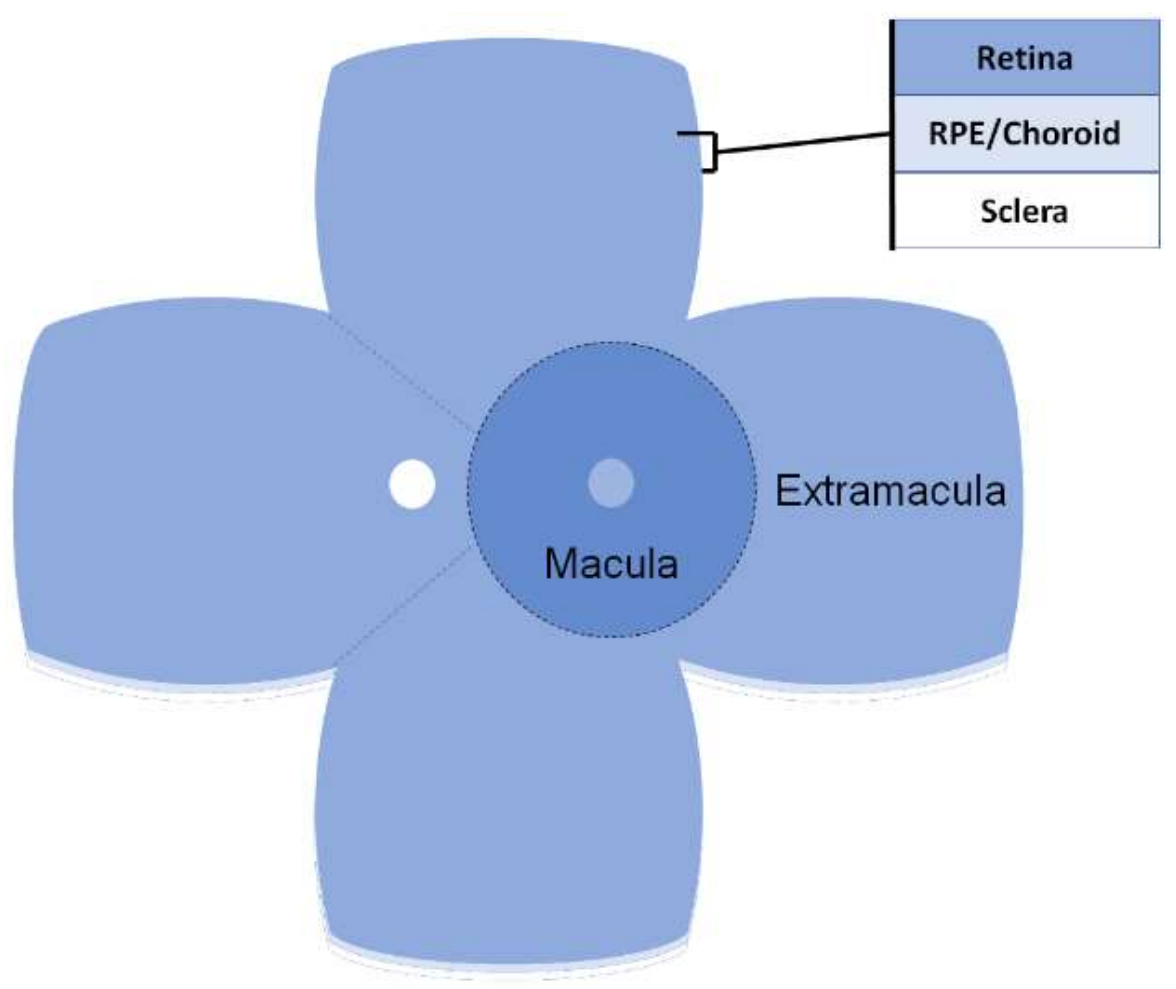

Figure 1: Ocular tissue layers and geographical regions relevant for AMD-associated transcriptome analysis. Figure adapted from Morgan et al. ${ }^{25}$ 
medRxiv preprint doi: https://doi.org/10.1101/2020.12.28.20248962; this version posted January 4, 2021. The copyright holder for this preprint (which was not certified by peer review) is the author/funder, who has granted medRxiv a license to display the preprint in perpetuity.

It is made available under a CC-BY-NC-ND 4.0 International license .

Tissue-specific differential gene expression in AMD

\section{BLOC1S1 (probe: A_23_P53298) mRNA Expression \\ $A M D$ vs. Normal Retina \& RPE/Choroid Tissues}

Source: GSE29801, Agilent Whole Human Genome Microarray 4x44K G4112F

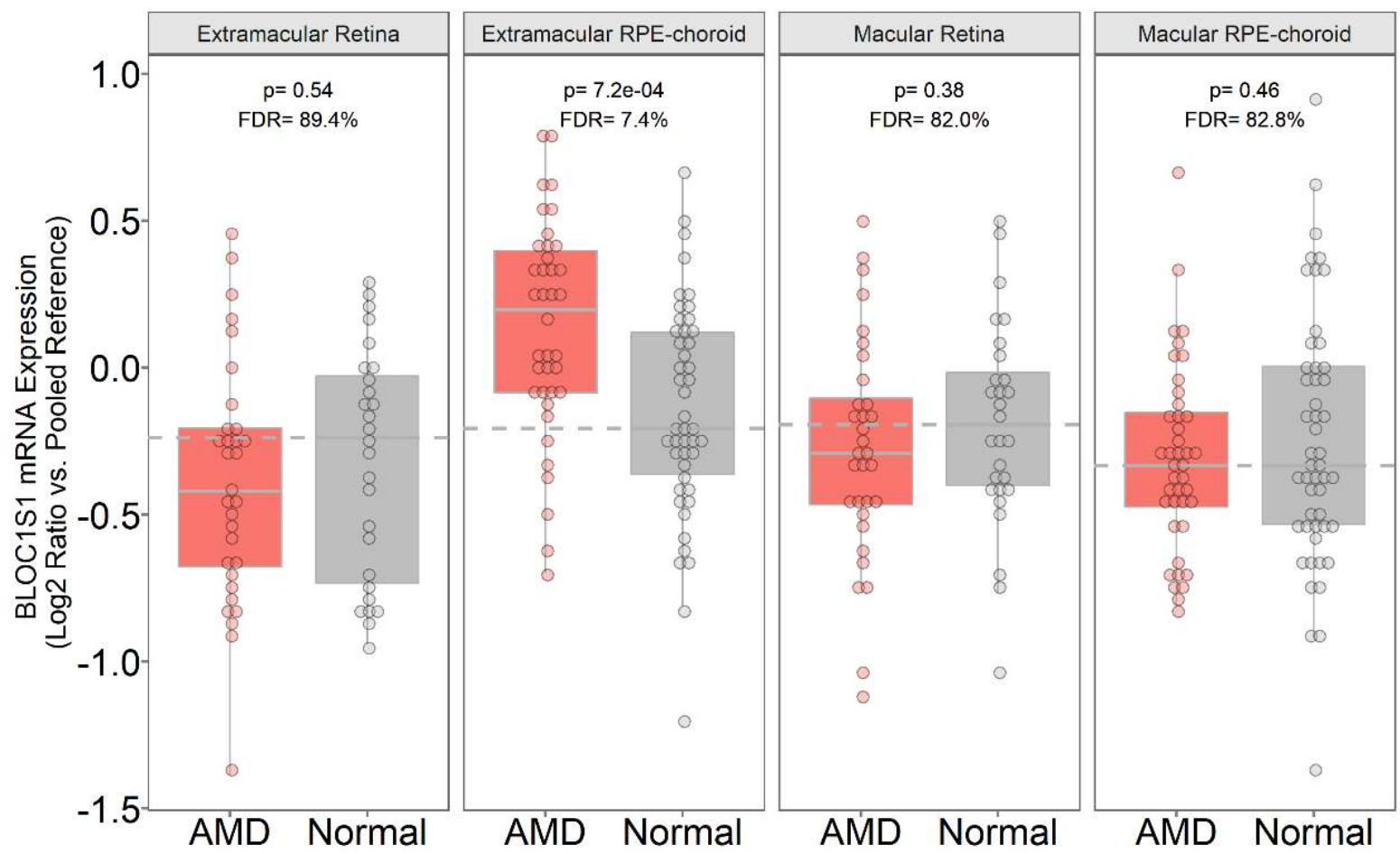

Figure 2: BLOC1S1 mRNA expression across ocular tissue types. Dotted horizontal lines indicate the median log2-transformed intensity ratio comparing the relevant tissue/regionspecific normal samples to the pooled reference. 